\title{
Peptidase with Keratinolytic Activity Secreted by Aspergillus terreus During Solid-State Fermentation
}

\author{
Ana Claudia Rodrigues de Siqueira ${ }^{1}$, Nathalia Gonsales da Rosa $^{1}$, Cristina Maria Souza \\ Motta $^{2}$ and Hamilton Cabral ${ }^{1 *}$ \\ ${ }^{1}$ Departamento de Ciências Farmacêuticas; Faculdade de Ciências Farmacêuticas de Ribeirão Preto; Universidade \\ de São Paulo; Ribeirão Preto - SP - Brasil. ${ }^{2}$ Departamento de Micologia; Centro de Ciências Biológicas; \\ Universidade Federal de Pernambuco; Recife - PE - Brasil
}

\begin{abstract}
The aim of this study was to evaluate peptidase production by Aspergillus terreus in solid-state bioprocess and evaluate its parameters. The best conditions were $5.0 \mathrm{~g}$ of wheat bran as substrate, incubation temperature $30^{\circ} \mathrm{C}$, inoculum $2.0 \times 10^{5}$ spores $/ \mathrm{g}$ and $75 \%$ saline volume, with production reaching $677 \mathrm{U} / \mathrm{mL}(5400 \mathrm{U} / \mathrm{g}$ culture medium) after $72 \mathrm{~h}$ of fermentation. Biochemical characterization of the crude enzymatic extract showed the optimum $\mathrm{pH}$ and temperature of 6.5 and $55^{\circ} \mathrm{C}$, respectively. The stability at different temperatures and $\mathrm{pH}$ values showed that the extract could endure different $p H$. The evaluation of the ions influence and inhibitors proved that the enzyme required an ion for better activity, which was corroborated with the inhibition of EDTA and PMSF, characterizing serine and/or metallo peptidase. The extract was also tested for specific activities and showed promising results for keratinolytic and collagenolytic activities $(0.252$ and $0.165 \mathrm{OD} / \mathrm{mL}$, respectively).
\end{abstract}

Key words: protease, solid-state fermentation, keratinase, wheat bran, Aspergillus terreus

\section{INTRODUCTION}

Fermentation uses a microorganism to obtain biotechnological products, such as enzymes (Pereira et al. 2008). In solid-state fermentation processes, there is lack of free water in the culture medium, with only enough amount to maintain the growth of the microorganism (Pandey et al. 2000). In these processes, the solid material most often used is agro-industrial waste, which serves both as physical support and as a nutrient source (Pandey 2003). This type of process has advantages, such as better biomass production in a short period of time and similarity to the natural habitat. The downstream processes are facilitated by the high concentration of the product, thereby potentially increasing the earned value to the final product.
Hence, this process is a great technology for obtaining the products and potential use of solid residues (Soccol and Vandenbergh 2003; Graminha et al. 2008).

Enzyme production by solid-state fermentation has been studied extensively. Peptidases are enzymes that have been found in different types of culture medium using agro-industrial waste, such as wheat bran (WB) (Tunga et al. 1998; Uyar and Baysal 2004), wheat and soybean flours (Wang et al. 2005) and rice straw (Chapla et al. 2010). These enzymes have applications in different areas of industry, including pharmaceuticals and cosmetics, food, leather, detergents and bioremediation and waste treatment (Anwar and Saleemuddin 1997; Rao et al. 1998; Sharma et al. 2001; Gupta et al. 2002; Novozymes 2008).

*Author for correspondence: hamilton@fcfrp.usp.br 
Microorganisms are interesting sources of peptidases because they have wide biochemical diversity, easy cultivation and maintenance, a reduced cost and the possibility of genetic manipulation for the improvement or modification of the final product. Therefore, microbial peptidases are among the most important hydrolytic enzymes currently used. There is, thus, a constant search for new peptidase producers, including filamentous fungi and new culture media and conditions for cultivation that can increase the yields and decrease the costs of production (Ladeira et al. 2010).

The filamentous fungus Aspergillus terreus is known for producing important biotechnological products, such as lovastatin and itaconic acid (Benett 2010). There is an interest in generating other products, such as enzymes, including peptidases. The goal of this study was to determine the best parameters for peptidase production by $A$. terreus, its characterization and potential applications.

\section{MATERIALS AND METHODS}

\section{Microorganism and maintenance}

A. terreus was obtained from the culture bank of the enzyme technology laboratory of the Faculty of Pharmaceutical Sciences of Ribeirão Preto. The fungus was isolated from a feather found in the soil in Miguelópolis, São Paulo state, Brazil. The strain was identified by Dr Cristina Maria S Motta at the Mycology Department of the Federal University of Pernambuco - UFPE and was grown on potato dextrose agar (PDA) in culture tubes by incubating at $30^{\circ} \mathrm{C}$ for $168 \mathrm{~h}$.

\section{Inoculum preparation}

An inoculum was prepared by adding sterile saline solution $\left(0.1 \% \quad \mathrm{w} / \mathrm{v} \quad\left(\mathrm{NH}_{4}\right)_{2} \mathrm{SO}_{4}, \quad 0.1 \% \quad \mathrm{w} / \mathrm{v}\right.$ $\mathrm{NH}_{4} \mathrm{NO}_{3}$ and $0.1 \%$ w/v $\mathrm{MgSO}_{4} \cdot 7 \mathrm{H}_{2} \mathrm{O}$ ) and scraping the surface to form a spore solution. The spore concentration was determined by counting in a Neubauer chamber. The volume added was variable and the total volume of the solution was $10 \mathrm{~mL}$ (Merheb-Dini et al. 2007).

\section{Solid-State Fermention (SSF)}

Adapted from the techniques of Lotong and Suwanarit (1985) and Merheb-Dini et al. (2007), the method for peptidase production in SSF used autoclavable polypropylene bags of $12 \times 20 \mathrm{~cm}$ to which $5.0 \mathrm{~g}$ of the substrate and $8.0 \mathrm{~mL}$ of saline solution as above was added and then autoclaved at $121^{\circ} \mathrm{C}$ for $40 \mathrm{~min}$. The bags after inoculation were incubated at $30^{\circ} \mathrm{C}$. Every $24 \mathrm{~h}$, one bag was removed and $40 \mathrm{~mL}$ of distilled water at $4^{\circ} \mathrm{C}$ was added. The extraction of enzyme was performed by soaking and agitation. The material was filtrated and centrifuged at $5,000 \mathrm{xg}$ at $4^{\circ} \mathrm{C}$ for 20 min. The supernatant was considered as crude enzymatic extract and was used for proteolytic activity tests.

The composition of the culture medium included $5.0 \mathrm{~g}$ of WB only or supplemented with 5,10 or $20 \%$ casein or albumin or $5.0 \mathrm{~g}$ of cottonseed (CS) meal only or supplemented with 5,10 or $20 \%$ soy protein, gluten or WB. After determining the best agro-industrial waste for peptidase production, other parameters were varied to define the optimum conditions for the production of enzyme, including the spore concentration $\left(5.0 \times 10^{6}\right.$, $2.5 \times 10^{6}$ or $1.0 \times 10^{6}$ spores $\left./ \mathrm{mL}\right)$, temperature $(30$, 35,40 and $\left.45^{\circ} \mathrm{C}\right)$ and saline volume $(65,75,85$ or $100 \%$, w/v), which was calculated based on the grams of the WB and saline (15 g) as $100 \%$.

\section{Proteolytic activity using casein as substrate}

Proteolytic activity was determined using the protocols described by Sarath et al. (2001), with modifications. The assay used was performed in triplicate using $1 \%$ casein dissolved in monobasic sodium phosphate buffer (50 Mmol/L, $\mathrm{pH} 6.5$ ). The assay was carried out using $150 \mu \mathrm{L}$ of crude enzymatic extract, $100 \mu \mathrm{L}$ of monobasic sodium phosphate buffer (50 Mmol/L, $\mathrm{pH} 6.5)$ and 1000 $\mu \mathrm{L}$ of $1 \%$ casein, incubating the mixture at $40^{\circ} \mathrm{C}$ for at least $60 \mathrm{~min}$, after which the reaction was stopped using $600 \mu \mathrm{L}$ of $10 \%$ trichloroacetic acid (TCA). TCA was added to blank tubes before casein to precipitate the enzyme. The tubes were centrifuged at $10,000 \mathrm{xg}$ at room temperature for $15 \mathrm{~min}$. The supernatants were measured against blanks in quartz cuvettes at $280 \mathrm{~nm}$. The amount of enzyme required to result an increase of $0.001 \mathrm{~A}_{280 \mathrm{~nm}}$ under assay conditions was defined as one unit of enzyme (Sarath et al. 2001).

\section{Protein precipitation}

The crude enzymatic extract was subjected to precipitation using fractionation at proportion of $1: 3$ of crude enzymatic extract and ethanol $92.6^{\circ} \mathrm{GL}$. The material was kept at $-20^{\circ} \mathrm{C}$ for $24 \mathrm{~h}$ and then centrifuged at $10,000 \times \mathrm{xg}$ at $4^{\circ} \mathrm{C}$ for 30 min. The supernatant was discarded and the pellet was resuspended under mild agitation in 
monobasic sodium phosphate buffer $(50 \mathrm{Mmol} / \mathrm{L}$, $\mathrm{pH} 6.5)$ at $4^{\circ} \mathrm{C}$. This new extract was used for proteolytic activity assay using azo-casein as substrate.

\section{Biochemical Enzyme Characterization}

\section{Proteolytic Activity using Azo-casein as Substrate}

The protocol for assessing the proteolytic activity using azo-casein as a substrate was based on an assay reported by Sarath et al. (2001) with modifications. The reaction was performed using $100 \mu \mathrm{L}$ of precipitate extract, $100 \mu \mathrm{L}$ of indicate buffer and $200 \mu \mathrm{L}$ of $1 \%$ azo-casein. This mixture was incubated for $10 \mathrm{~min}$ at indicated temperature. The reaction was stopped by adding $800 \mu \mathrm{L} 10 \%$ TCA. TCA was added to blank tubes before azocasein to precipitate the enzyme. The tubes were centrifuged at $10,000 \mathrm{xg}$ at room temperature for $15 \mathrm{~min}$. Then, $800 \mu \mathrm{L}$ of supernatant was added to $933 \mu \mathrm{L}$ of $1 \mathrm{M}$ sodium hydroxide. This mixture was measured against blank in plastic cuvettes at $440 \mathrm{~nm}$. All the experiments were performed in triplicate. The amount of enzyme required to result an increase of $0.001 \mathrm{~A}_{440 \mathrm{~nm}}$ under the assay conditions was defined as one unit of enzyme (Sarath et al. 2001).

\section{Optimum pH and temperature}

To optimize the $\mathrm{pH}$ of the precipitated extract following buffers were used: acetate $(\mathrm{pH} 4.5$ and 5.0), 2-( $N$-morpholino)ethanesulfonic acid (MES) $(\mathrm{pH} 5.5,6.0$ and 6.5), 4-(2-hydroxyethyl)-1piperazineethanesulfonic acid (HEPES) ( $\mathrm{pH} 7.0$, 7.5 and 8.0), bicine (pH 8.5 and 9.0) and CAPS (pH 9.5, 10.0 and 10.5), all at $50 \mathrm{mM} / \mathrm{L}$. After the determination of the optimum $\mathrm{pH}$, the influence of temperature was examined for a range of 30 to $75^{\circ} \mathrm{C}$, with increments of $5^{\circ} \mathrm{C}$.

\section{Enzymatic extract stability}

Thermal stability was determined by incubating the enzyme at 30 to $65^{\circ} \mathrm{C}$ for $5,10,15$ and 60 minutes, after which proteolytic activity was assayed at $55^{\circ} \mathrm{C}$ and $\mathrm{pH} 6.5 . \mathrm{pH}$ stability was assessed by pre-incubating the precipitate extract at $25^{\circ} \mathrm{C}$ for $1 \mathrm{~h}$ in different buffers ranging from $\mathrm{pH} 4.5$ to 10.5 , with increments of 0.5 . Proteolytic activity was then assayed at $55^{\circ} \mathrm{C}$ and $\mathrm{pH} 6.5$.

\section{Effect of inhibitors and ions}

To determine the mechanism of action of the enzyme, the effects of inhibitors were determined according to the protocol of Dunn (1989), with modification. The inhibitors used were iodoacetic acid (IAA), phenylmethylsulfonyl fluoride (PMSF) and ethylene-diaminetetraacetic acid (EDTA), each at a final concentration of 10 $\mathrm{mM} / \mathrm{L}$. The effect of ions was determined using $\mathrm{NaCl}, \mathrm{MnCl}_{2}, \mathrm{KCl}, \mathrm{LiCl}, \mathrm{ZnSO}_{4}, \mathrm{CoCl}, \mathrm{CuCl}$, $\mathrm{CaCl}_{2}, \mathrm{MgCl}_{2}, \mathrm{BaCl}_{2}$ and $\mathrm{AlCl}_{3}$, each at a final concentration of $10 \mathrm{mM} / \mathrm{L}$.

\section{Evaluation of collagenase activity}

Collagenolytic activity was based on a protocol described by Jiang et al. (2007), with modifications. In brief, $200 \mu \mathrm{L}$ of crude enzymatic extract was added to a suspension of 1.5 $\mathrm{g} / \mathrm{L}$ azocoll in $1.0 \mathrm{~mL}$ of HEPES buffer $(100$ $\mathrm{mM} / \mathrm{L}, \mathrm{pH} 7.0$ ) and incubated at $45^{\circ} \mathrm{C}$ for $70 \mathrm{~min}$, in triplicate. Samples of this mixture were transferred into tubes and centrifuged at 10,000 $\mathrm{xg}$ at room temperature for $10 \mathrm{~min}$. The supernatants were measured against the blanks at $550 \mathrm{~nm}$. The blanks were prepared similarly to the sample tubes, but the crude enzymatic extract was boiled for $10 \mathrm{~min}$ to inactivate the enzyme. The results were expressed as optical density (OD) per $\mathrm{mL}$ of crude enzymatic extract at $550 \mathrm{~nm}$ according to Jiang et al. (2007).

\section{Evaluation of keratinase activity}

The assay for keratinase activity was performed in triplicate using keratin-azure prepared in aqueous solution at $4 \mathrm{mg} / \mathrm{mL}$ according to Bressollier et al. (1999), with modification. The tests were performed using $200 \mu \mathrm{L}$ of crude enzymatic extract, $250 \mu \mathrm{L}$ of substrate suspension and 750 $\mu \mathrm{L}$ of HEPES buffer $(100 \mathrm{mM} / \mathrm{L}, \mathrm{pH} 7.0)$. This mixture was incubated at $45^{\circ} \mathrm{C}$ for $24 \mathrm{~h}$. The tubes were centrifuged at $10,000 \mathrm{xg}$ at room temperature for $10 \mathrm{~min}$ and measured against the blanks at 595 $\mathrm{nm}$. The blanks were prepared similarly to the sample tubes, but the crude enzymatic extract was boiled for $10 \mathrm{~min}$ to inactivate the enzyme. The results were expressed as OD per $\mathrm{mL}$ of crude enzymatic extract at $595 \mathrm{~nm}$ (Foroughi et al. 2006).

\section{RESULTS AND DISCUSSION}

Figure 1 shows the production of peptidases by $A$. terreus using agro-industrial residues, WB and CS meal, combined with certain other protein sources 
(casein, albumin, gluten and soy protein). Under the conditions tested, the best medium for peptidase production was WB without
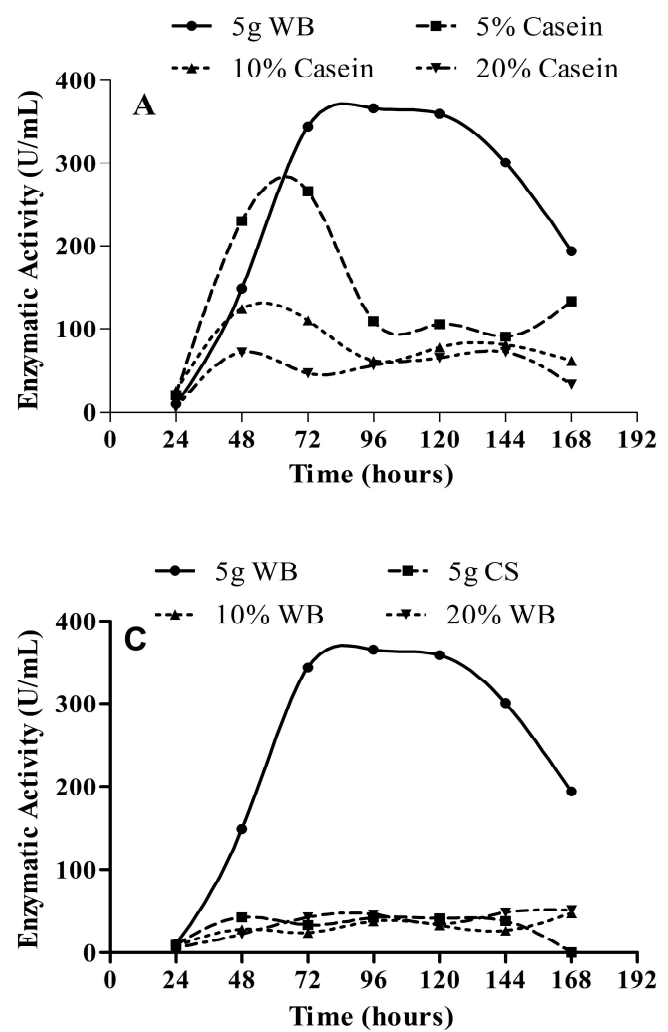

supplementation, resulting in the production of approximately $400 \mathrm{U} / \mathrm{mL}$ after $72 \mathrm{~h}$.
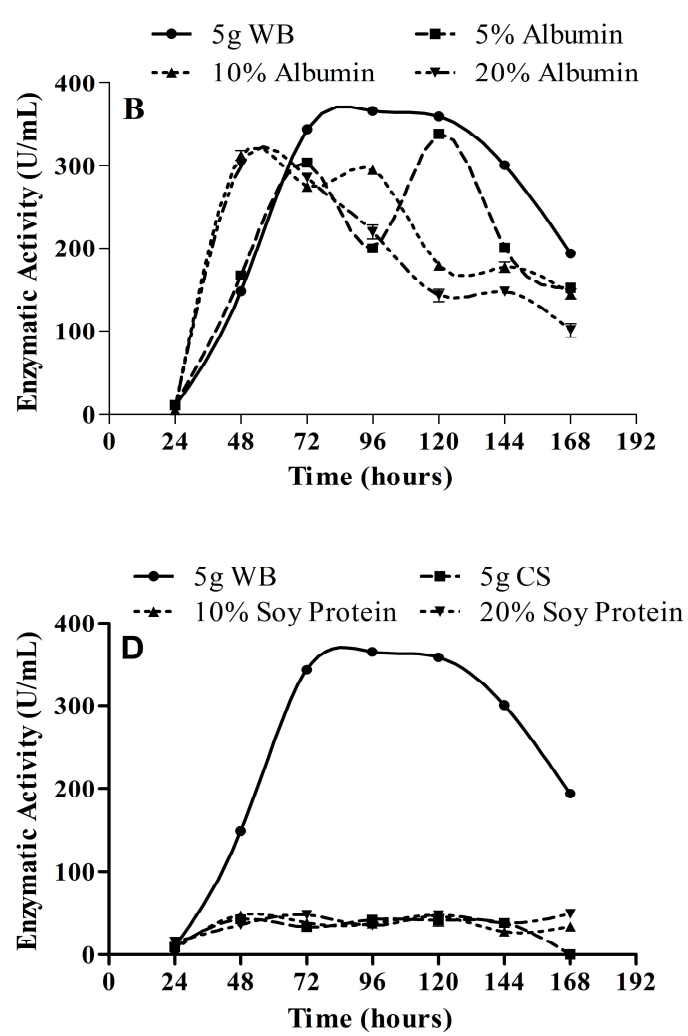

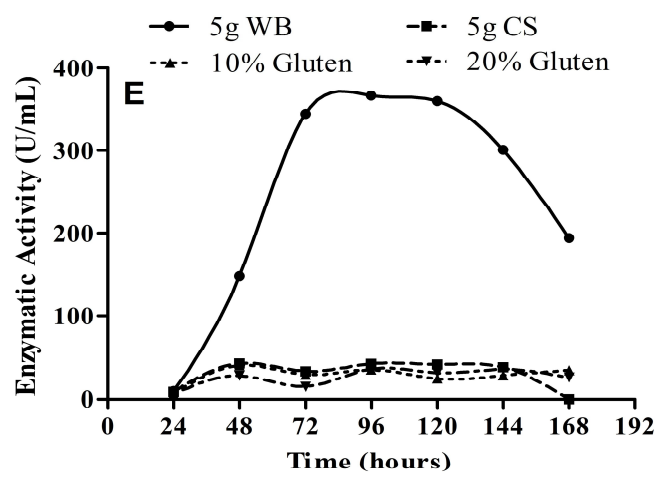

Figure 1 - Influence of different media on the production of peptidase by Aspergillus terreus. (A) WB and supplementation with casein; (B) WB and supplementation with albumin; (C) WB and CS and supplementation with WB; (D) WB and CS and supplementation with soy protein; (E) WB and CS and supplementation with gluten. These tests were performed at $30^{\circ} \mathrm{C}$, $65 \%$ of saline volume and $5 \times 10^{5}$ spores $/ g$.

The results showed that the use of protein sources other than WB was not efficient for the production of peptidase. According to Abidi et al. (2008), the presence of protein sources as inducers in the culture medium affects the production and secretion of peptidases by Botrytis cinerea. In this study, the supplementation with casein (Fig. 1A) or albumin (Fig. 1B) decreased peptidase production when used along with WB, except in $48 \mathrm{~h}$ production where $5 \%$ of casein, 10 and $20 \%$ of albumin showed better results than the use of WB only. In comparison of supplemental albumin 
or casein, albumin showed better result than casein. However, the production by WB alone was the highest.

In the bioprocess using CS meal, the production of peptidase was lower than with WB (10-times difference). The protein composition of the substrates was not the best explanation for these results because WB had approximately $16.58 \%$ protein and CS had 30.76\% (Filho et al. 2000). This could be due to a difference between the particle sizes of the two residues, which might reduce the accessibility of the substrate or the voids occupied by oxygen (Krishna 2005).

Spore concentration is important in the fermentation process because it can modulate the production of enzyme in the culture medium due to the availability of material to be degraded. Based on production profiles, concentrations of $5.0 \times 10^{5}$ and $2.0 \times 10^{5}$ spores $/ g$ resulted significant increase in the production compared with $1.0 \times 10^{6}$ spores/g (Fig. 2). Thus, the spore concentration selected for further experiments was $2.0 \times 10^{5}$ spores/g because this condition combined the best peptidase production after $72 \mathrm{~h}$.

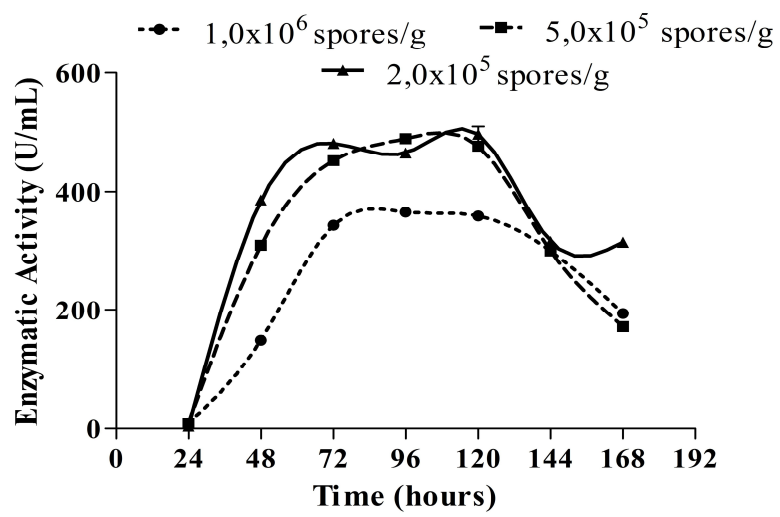

Figure 2 - Influence of spore concentration on peptidase production by the fungus Aspergillus terreus, in culture medium with $5 \mathrm{~g}$ of $\mathrm{WB}$ incubated at $30^{\circ} \mathrm{C}$ and $65 \%$ of saline volume.

An increase of spore concentration might have caused a faster depletion of essential nutrients so that there was no need for more peptidase production, whereas with a decrease in the spore concentration, enzyme production was enhanced. The cultivation temperature interferes with the growth and metabolism of the fungus, and consequently, peptidase production may vary. The best temperature was $30^{\circ} \mathrm{C}$ (Fig. 3), at which best results were obtained at all the sampling periods with maximum being $500 \mathrm{U} / \mathrm{mL}$. At $35^{\circ} \mathrm{C}$, only one peak of approximately $420 \mathrm{U} / \mathrm{mL}$ and a decrease in activity beginning at $96 \mathrm{hs}$ was observed. The results indicated that the fungus was sensitive to temperature. An increase in temperature promotes the higher evaporation of water from the fermentation, which causes cell death or an absence of spore germination. Thus, there was a decrease in peptidase production and secretion, with low levels at 40 and $45^{\circ} \mathrm{C}$.

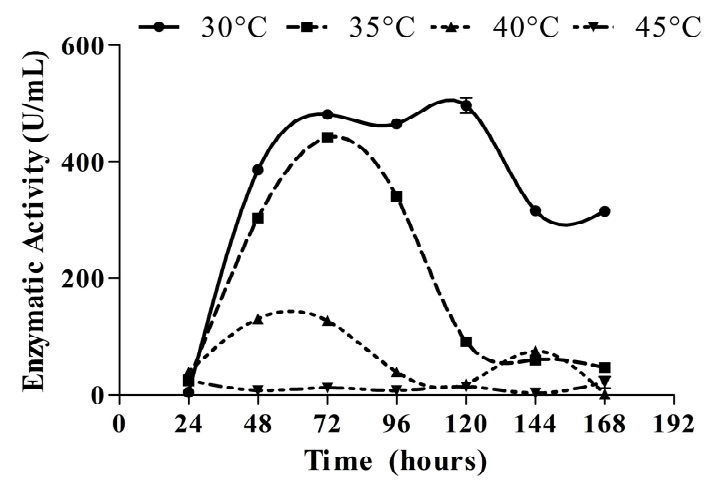

Figure 3 - Influence of the bioprocess temperature on peptidase production by the fungus Aspergillus terreus in culture medium containing $5 \mathrm{~g}$ of $\mathrm{WB}$ and $2.0 \times 10^{5}$ spores/g and at $65 \%$ saline volume.

The variation of saline volume presented in solid medium is proportional to the content of free water and may also affect the levels of peptidase production by A. terreus. As shown in Figure 4, $75 \%$ of saline volume provided the best performance, but $65 \%$ showed similar levels in certain periods of the bioprocess. Increase in the saline volume to 85 or $100 \%$ affected peptidase production, which was decreased to nearly half of the production under the best condition ( $75 \%)$.

The above results could be related to the fact that humidity affected the porosity of the culture medium, and therefore, compromised oxygenation, fungal growth and consequently peptidase or other metabolite production (Pandey 1992). The peak of peptidase production was $677 \mathrm{U} / \mathrm{mL}(5400 \mathrm{U} / \mathrm{g}$ medium) after $72 \mathrm{~h}$ of fermentation, using $5 \mathrm{~g}$ of WB at $30^{\circ} \mathrm{C}$, a spore concentration of $2.0 \times 10^{5}$ spores/g and $75 \%$ of saline volume. The first production obtained a peak around $370 \mathrm{U} / \mathrm{mL}$ after $96 \mathrm{~h}$ of fermentation and the optimization led to an increase of 1.8 times of activity and shifted the peak for $72 \mathrm{~h}$ of the bioprocess. Different species 
of Aspergillus sp in similar culture medium showed peptidase production similar to the production in this work, with peaks of 400 to 800 $\mathrm{U} / \mathrm{mL}$, as reported by Macchione et al. (2008).

In a study using the same culture medium (5 $\mathrm{g}$ of WB) with supplementation with egg albumin and casein, the production of peptidase by Penicillium corylophilum reached a peak of $520 \mathrm{U} / \mathrm{mL}$ after $96 \mathrm{~h}$ using only WB, and the production by Penicillium waksmanii was slightly increased using supplementation, with peak of $545 \mathrm{U} / \mathrm{mL}$ after $72 \mathrm{~h}$. However, the supplementation could be removed to generate cheaper medium because the peak with $5 \mathrm{~g}$ of WB alone was approximately 500 U/mL (Silva et al. 2013a). Similar to this, the present work showed that $A$. terreus did not require an external source of nitrogen for the production of peptidase and possessed the potential as a peptidase producer.

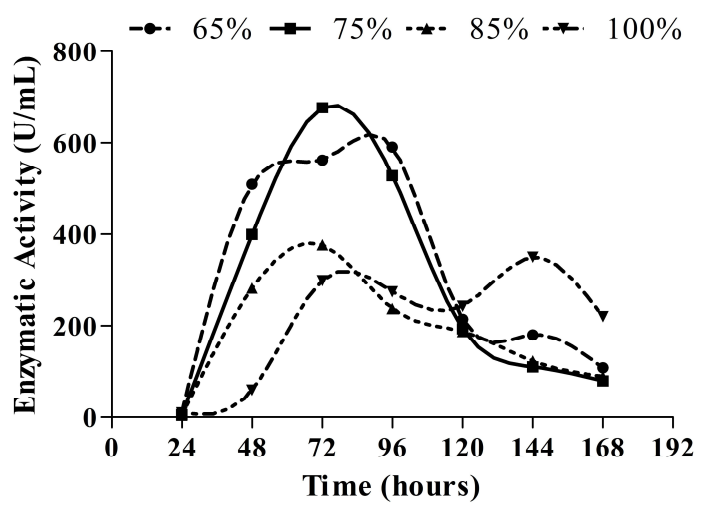

Figure 4 - Influence of the saline volume on peptidase production by the fungus Aspergillus terreus in culture medium containing $5 \mathrm{~g}$ of $\mathrm{WB}$ and $2.0 \times 10^{5}$ spores/g and incubated at $30^{\circ} \mathrm{C}$.

\section{Biochemical characterization - optimum pH and temperature}

Enzymes exhibit structural effects following $\mathrm{pH}$ variation. Changes in $\mathrm{pH}$ may modify the chemical structure of an enzyme due to protonation and deprotonation of the amino acid residues. The effects of the protonation and deprotonation of the catalytic site reflect the optimum $\mathrm{pH}$ of an enzyme (Tipton et al. 2009). In this study, azo-casein was used as a substrate in a $\mathrm{pH}$ range of 4.5 to 10.5 . The higher activities were reached at $\mathrm{pH} 5.5$ to 8.0 , and optimal activity was at $\mathrm{pH} 6.5$. The decrease in activity started at $\mathrm{pH} 8.5$ indicating better tolerance to alkaline $\mathrm{pH}$. This decrease might be due to the protonation of several amino acid residues, or a structural modification that promoted the inactivation, or denaturation of the peptidase (Fig. 5).

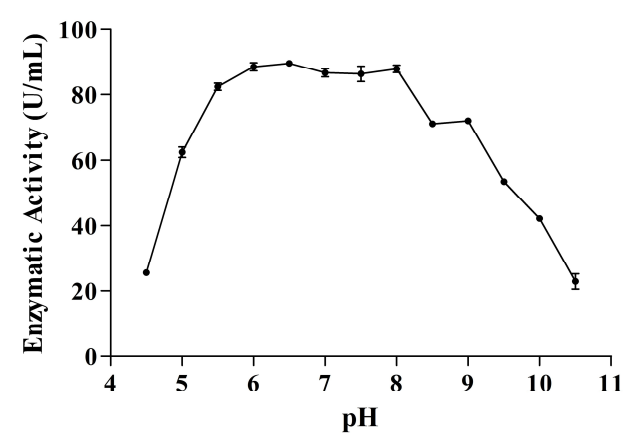

Figure 5 - Influence of $\mathrm{pH}$ (range of 4.5 to 10.5) on enzymatic activity. Assays with azo-casein at $45^{\circ} \mathrm{C}$.

The effect of temperature on the proteolytic activity was determined based on the hydrolysis of azo-casein incubated at different temperatures and at an optimum $\mathrm{pH}$. The optimum temperature for the reaction was determined at $55^{\circ} \mathrm{C}$ (Fig. 6). Above $55^{\circ} \mathrm{C}$, there was a decrease in proteolytic activity, possibly by denaturation of the enzyme by breaking the chemical bonds with thermal energy. Below $55^{\circ} \mathrm{C}$, with increasing temperature, proteolytic activity also increased, which was related to the increased agitation of the molecules colliding with the substrate, promoting the better formation of products.

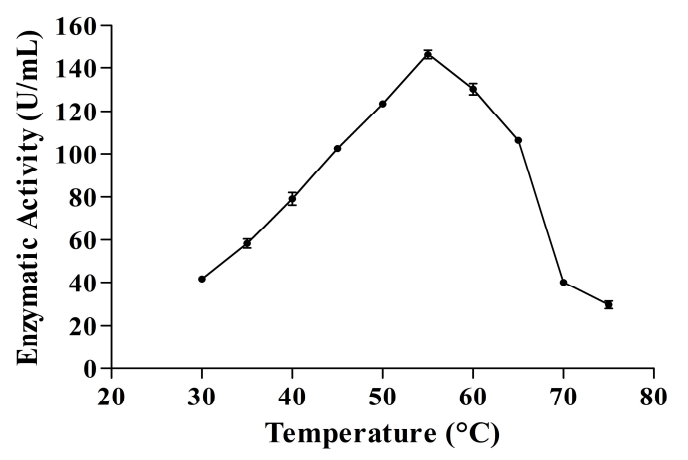

Figure 6 - Influence of temperature (range of $30^{\circ} \mathrm{C}$ to $75^{\circ} \mathrm{C}$ ) on enzymatic activity. Assays with azo-casein on $\mathrm{pH} 6.5$.

\section{Enzymatic extract stability}

The effects of temperature and $\mathrm{pH}$ on the stability of the enzymatic extract were determined based on the hydrolysis of azo-casein incubated at different temperatures and $\mathrm{pH}$ values. These assays are 
important for the certification of enzyme stability for a subsequent application. The enzymatic extract was only partially purified, therefore, did not contain just the enzyme. The presence of different other proteins, carbohydrates, or other particles could affect the enzyme activity and stability, interfing positively, or negatively. The temperature stability of the enzymatic extract was $30^{\circ} \mathrm{C}$, maintaining activity close to $50 \%$ for $1 \mathrm{~h}$ (Fig. 7A). Figure 7B shows the performance of the

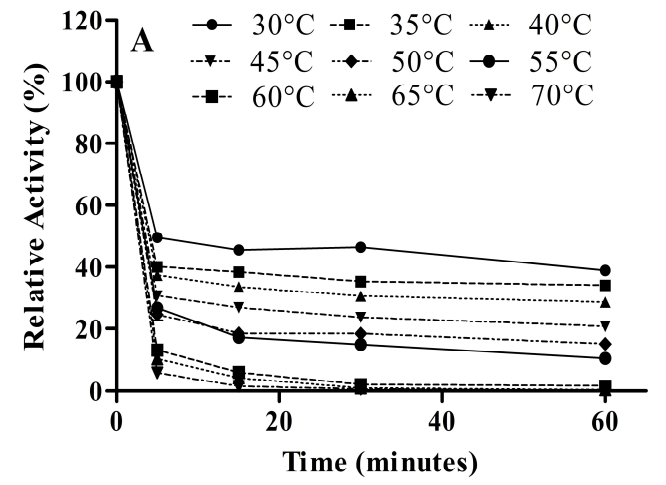

extract in a $\mathrm{pH}$ range of 4.5 to 10.5 . This showed better stability at an acidic $\mathrm{pH}$ (4.5 to 6.0). Despite the decrease in the activity with an increase in $\mathrm{pH}$, the decrease was not under $50 \%$.

Stability is an important parameter given the different applications of enzymes and extracts in industrial processes. From these tests, it was obvious that an extract could be used in complex processes, or be preserved by stabilization techniques (Ameri and Maa 2006; Namaldi et al. 2006).

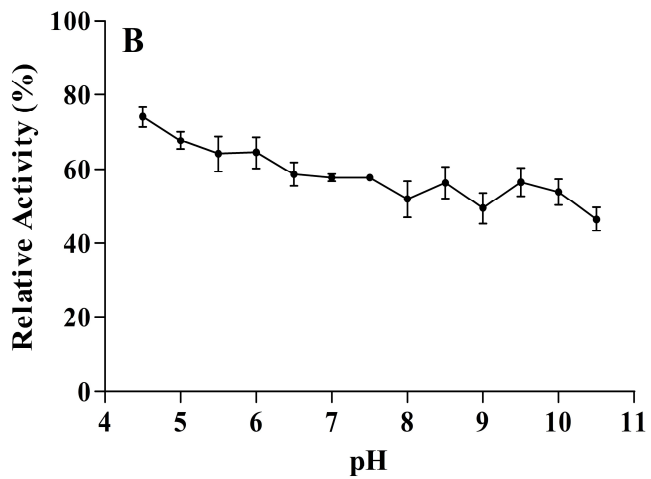

Figure 7 - (A) Temperature stability at exposure times of 5, 15 and $60 \mathrm{~min}$; (B) $\mathrm{pH}$ stability (range of 4.5 to 10.5$)$ and enzymatic activity over $1 \mathrm{~h}$.

\section{Effect of inhibitors and ions}

The classification of the peptidase based on the nature of the catalytic site was determined by an inhibitor assay. This assay showed that there might be more than one peptidase in the extract or only one metal-dependent peptidase because EDTA and PMSF were inhibitory. These inhibitors indicated serine and metallo peptidases, respectively (Fig. 8).

The modulation of enzymatic activity in the presence of ions may be positive when there is an increase in proteolytic activity compared with a control, or negative when this activity decreases. Ions can interact with the enzyme through residues in the catalytic site, modifying the residues' disposal promotes the activation or inactivation of the enzyme. Another explanation for the modulation by ions is interaction with amino acids outside of the catalytic site, promoting the modification of tertiary structure and improving or not improving proteolytic activity. As noted, the peptidase in the precipitate extract presented positive modulation, with increases of 120 and $110 \%$ in the presence of $\mathrm{Ca}^{2+}$ and $\mathrm{Al}^{3+}$, respectively. There was negative modulation when the enzyme was exposed to lithium and copper, which possibly bonded to the serine residue in the catalytic site of the peptidase, causing a loss of activity (Fig. 9). Hajji et al. (2008) observed positive modulation when a serine peptidase produced by $A$. clavatus was incubated with calcium (124\%), with performance similar to the present study.

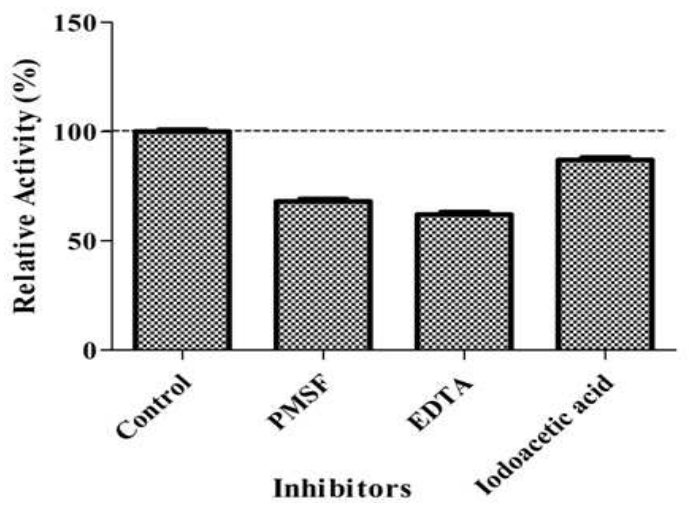

Figure 8 - Influence of the addition of inhibitors on the proteolytic activity of the peptidase produced by $A$. terreus. Proteolytic activity was determined using azo-casein at $55^{\circ} \mathrm{C}$ in MES buffer at $\mathrm{pH} \quad 6.5$ and a final concentration of $10 \mathrm{mM} / \mathrm{L}$. 


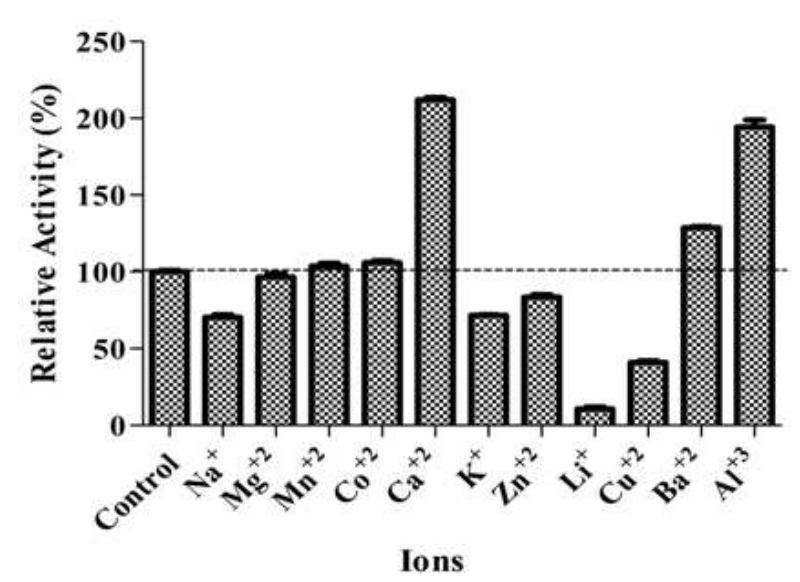

Figure 9 - Influence of the addition of ions on the proteolytic activity of the peptidase produced by Aspergillus terreus. Proteolytic activity was determined using azo-casein at $55^{\circ} \mathrm{C}$ in MES buffer at $\mathrm{pH}$ 6.5 and a final concentration of $10 \mathrm{mM} / \mathrm{L}$.

A study by Silva et al. (2013b) characterized a serine peptidase produced by A. fumigatus in SSF using WB; the enzyme showed similar characteristics to the peptidase in the current study. In another study by Stefanova et al. (1997), A. terreus produced two classes of peptidases, serine and metallo, which were responsible for the cleavage of low-mass endoglucanases. These studies showed the possibilities presented in this study, the presence of one ion-dependent serine peptidase, or two classes of peptidase, metallo and serine.

\section{Collagenolytic and keratinolytic potential}

The keratinolytic activity obtained was 0.252 $\mathrm{OD} / \mathrm{mL}$ in 24 hours, showing the potential of this extract in the degradation of keratin. Foroughi et al. (2006) reported that the extracts of different fermentations obtained results of 0.02 to 0.09 $\mathrm{OD} / \mathrm{mL}$ over 24 hours, showing that under the conditions in the present study the result was better. The collagenolytic activity showed a result of $0.165 \mathrm{OD} / \mathrm{mL}$ in $70 \mathrm{~min}$, proving the extract's potential.

\section{CONCLUSION}

The agro-industrial residues were proven to be efficient substrate for peptidase production by $A$. terreus. The level of the proteolytic activity presented might be viable for use in industrial processes because of the low cost of the culture media, adding value to the product. The biochemical characterization of the precipitate extract showed the presence of two different peptidases (serine and metallo peptidases), or the existence of only one metal-dependent serine peptidase and a favorable behavior in a wide $\mathrm{pH}$ range. Thus, it could be possible the use of this enzyme in detergent industry, as it tolerated different $\mathrm{pH}$. It also could be used in residues treatment, as the ions did not have a negative influence in the enzymatic activity, except for lithium and cooper. The keratinolytic and collagenolytic potential proved to be important for the possible application of this extract, showing promise for others applications.

\section{ACKNOWLEDGMENTS}

The authors would like to acknowledge the financial support provided by Fundação de Amparo à Pesquisa do Estado de São Paulo, (2011/06986-0), Conselho Nacional de Desenvolvimento Científico e Tecnológico and Coordenação de Aperfeiçoamento de Pessoal de Nível Superior.

\section{REFERENCES}

Abidi F, Liman F, Nejib MM. Production of alkaline proteases by Botrytis cinerea using economic raw materials: Assay as biodetergent. Process Biochem. 2008; 43(11): 1202-1208.

Ameri A, Maa YF. Spray drying of biopharmaceuticals: stability and process considerations. Dry Technol. 2006; 24(6): 763-768.

Anwar A, Saleemuddin M. Alkaline proteases: a review. Bioresource Technol. 1997; 64: 175-183.

Benett JW. An overview of the genus Aspergillus. In: Masayuki, M, Katsuya, G, editors. Aspergillus: Molecular biology and genommics. Japan: Caister Academic Press; 2010. 1-15.

Bressollier P, Letourneau F, Urdaci M, Verneuil B. Purification an Characterization of a keratinolytic serine proteinase from Streptomyces albidoflavus. Appl Environ Microbiol. 1999; 65(6): 2570-2576.

Chapla D; Divecha J; Madamwar D; Shah A. Utilization of agro-industrial waste for xylanase production by Aspergillus foetidus MTCC 4898 under solid state fermentation and its application in saccharification. Biochem Eng J. 2010, 49: 361-369.

Dunn BM. Determination of protease mechanism. In: Beynon, RJ, Bond, JS, editors. Proteolytic Enzymes: a practical approach. USA: Oxford University Press; 1989. 57-81. 
Filho SCV, Silva FF, Júnior VRR, Capelle ER. Tabelas de composição de alimentos e exigências nutricionais para bovinos no Brasil. Proceedings of the II Simpósio de produção de gado de corte; 2000 Jun 1417; Viçosa, MG.

Foroughi F, Keshavarz T, Evans CS. Specificities of proteases for use in leather manufacture. J Chem Technol Biot. 2006; 81: 257-261.

Graminha EBN, Gonçalves AZL, Pirota RDPB, Balsalobre MAA, Silva R, Gomes E. Enzyme production by solid-state fermentation: Application to animal nutrition. Anim Feed Sci Technol. 2008; 144: $1-22$.

Gupta R, Beg QK, Khan S, Chauhan B. An overview on fermentation, downstream processing and properties of microbial alkaline proteases. Appl Microbiol Biot. 2002; 60: 381-395.

Hajji M, Rebai A, Gharsallah M, Nasri M. Optimization of alkaline protease production by Aspergillus clavatus ES1 in Mirabilis jalapa tuber powder using statistical experimental design. Appl Microbiol Biot. 2008; 79: 915-923.

Jiang N, Tan NS, Ho B, Ding JL. Azocoll protease activity assay. Nature publishing group; 2007. URL: http://dx.doi.org/10.1038/nprot.2007.484.

Krishna C. Solid state fermentation systems - An overview. Crit Rev Biotechnol. 2005; 25: 1-30.

Ladeira AS, Andrade MV, Delatorre AB, Perez VH, Martins LLM. Utilização de resíduos agroindustriais para a produção de proteases pelo termofílico Bacillus sp em fermentação submersa: otimização do meio de cultura usando a técnica de planejamento experimental. Quim Nova. 2010; 33 (2): 324-328.

Lotong N, Suwanarit P. Production of soy sauce koji mold spores inoculum in plastic bags. Appl Environ Microbiol. 1985; 46 (5): 1224-1226.

Macchione MM, Merheb-Dini CW, Gomes E, Silva R. Protease Production by Different Thermophilic Fungi. Appl Biochem Biotech. 2008; 146: 223-230.

Merheb-Dini CW, Cabral H, Gomes E, Da Silva R. Partial characterization of protease from a thermophilic fungus, Thermoascus aurantiacus, and its hydrolytic activity on bovine casein. Food Chem. 2007; 104: 127-131.

Namaldi A, Çalik P, Uludag Y. Effects of Spray Drying Temperature and Additives on the Stability of Serine Alkaline Protease Powders. Dry Technol. 2006: 24 (11): 1495-1500.

Enzymes at work - Novozymes [Internet]. 2008 (3) [updated 2013 May 5; cited Aug 28]. Available from: http://www.novozymes.com/en/about-us/brochures/ documents/enzymes_at_work.pdf

Pandey A. Recent process developments in solid-state fermentation. Process Biochem. 1992; 27: 109-117.
Pandey A, Soccol CR, Mitchell D. New developments in solid state fermentation I-bioprocesses and products. Process Biochem. 2000; 30: 1153-1169.

Pandey A. Solid-state fermentation. Biochem Eng J. 2003; 13: 81-84.

Pereira NJ, Bon EPS, Ferrara MA. Séries em biotecnologia: Tecnologia de bioprocessos. 1st ed. Rio de Janeiro: RJ; 2008; 1.

Rao MB, Tanksale AM, Ghatge MS, Deshpande VV. Molecular and biotechnological aspects of microbial proteases. Microbiol Mol Biol R. 1998; 62(3): 597635.

Sarath G, Zeeece MG, Penheiter AR. Protease assay methods. In: Beynon, R.J.; Bond J. S. Proteolytic enzyme: a practical approach. USA: Oxford University Press; 2001, 45-76.

Sharma R, Chisti Y, Banerjee UC. Production, purification, characterization, and applications of lipases. Biotechnol Adv. 2001; 19: 627-662.

Silva RR, Ângelo T, Cabral H. Comparative evaluation of peptidases produced by Penicillium corylophilum and Penicillium waksmanii in solid state fermentation using agro-industrial residues. J Agric Sci Technol. 2013; 3(3): 230-237.

Silva RR, Cabral TPF, Rodrigues A, Cabral H. Production and partial characterization of serine and metallo peptidases secreted by Aspergillus fumigatus Fresenius in submerged and solid state fermentation. Braz J Microbiol, 2013; 44(1): 235-243.

Soccol CR, Vandenberghe LPS. Overview of solid-state fermentation in Brazil. Biochem Eng J. 2003; 13: 205-218.

Stefanova ME, Beletskaya OP, Kulaev IS. Characterization of two extracelular proteinases from Aspergillus terreus and their role in the formation of low molecular weight endoglucanases. Process Biochem. 1997; 32 (8): 685-689.

Tipton KF, Mcdonald AG, Dixon HBF. Effects of pH on enzymes. In: Purich, DL, editor. Contemporary enzyme kinetics and mechanism, USA: Academic Press Elsevier; 2009. 124-177.

Tunga R, Shrivastava B, Banerjee R. Purification and characterization of a protease from solid state culture of Aspergillus parasiticus. Process Biochem. 2003; 38, 1553-1558.

Wang SL, Chen YH, Wang CL, Yen YH, Chern MK. Purification and characterization of a serine peptidase extracellularly produced by Aspergillus fumigatus in a shrimp and crab shell powder medium. Enzyme Microb Tech. 2005; 36: 660-665.

Uyar F, Baysal Z. Production and optimization of process parameters for alkaline protease production by a newly isolated Bacillus sp. Under solid state fermentation. Process Biochem. 2004; 39: 1893-1898. 